\title{
XLVII. On the early blowing of plants during the present winter
}

\section{Dr. Thomas Forster F.L.S.}

To cite this article: Dr. Thomas Forster F.L.S. (1822) XLVII. On the early blowing of plants during the present winter , Philosophical Magazine Series 1, 59:287, 212-213, DOI: $10.1080 / 14786442208652721$

To link to this article: http://dx.doi.org/10.1080/14786442208652721

里 Published online: 29 Jul 2009.

Submit your article to this journal $\sqsubset \pi$

Џ Article views: 2

Q View related articles $\asymp$ 


\section{[ 212$]$}

XLVII. On the early Blowing of Plants during the present Winter. By Dr. Thomas Fonster, F.L.S. \&̈c. Eंc.

$$
\text { To Dr. Tilloch. }
$$

SIR, - I PRoceed to send you an account of the unseasonable florescence of many plants this winter and spring, as I promised in my last paper on the Peculiarities of the Weather.

On the first of December a considerable number of plants belonging to the æstival and autumnal Floras remained in blow: among others may be reckoned the Chrysanthemum coronarium, Scabiosa atropurpurea, Papaver Rheeas, P. somniferum, and many varieties of Stocks. The following plants, however, came into flower after the first of December, and they opened their blossoms according to the dates subjoined.

December 2. Helleborus hyemalis.

4. Papaver Cambricum.

4. Adonis autumnalis.

4. Tussilago fragrans.

9. Primula Veris.

9. Primula elatior.

15. Vinca major.

16. Vilurnum Tinus.

24. Bellis perennis.

1522. January 4. Primula Polyanthi varii.

19. Lamium purpureum.

28. Primula vulgaris.

29. Galanthus nivalis.

February 6. Anemone hepatica.

6. Tussilago allia.

8. Crocus vernus.

19. Scilla Peruviana.

24. Anemone hortensis.

24. Daphne Mezereon.

24. Narcissus Romanus.

24. Tarcissus papyracells.

24. Viola tricolor.

25. Hyacinthus orientalis.

25. Narcissus Tazetta fluva.

March 1. Leontodon Taraxacum.

4. Ficaria verna.

4. Tussilago Farfara.

5. Hyacinihus Botryoides.

5. Scilla amona.

5. Narcissus Pseudonarcissus.

9. Narcissus lcetus.

9. Calendula 
March 9. Calendula officinalis.

9. Tussilago hybrida.

10. Viola Tunbrigiensis.

I shall like to see the calendars of Flora kept by any of your correspondents in other parts of England, if they will be so obliging as to communicate them. I remain, \&c.

'T. Forster.* EDit.

*In our last Number, p. 154, last line, for J. Forster read T. Forster.-

XLVIII. Notices respecting New Books.

Recent Publications.

Tables Astronomiques, publiées par le Bureau des Longitudes de France, contenant les Talles de Jupiter, de Saturne, et d'Uranus, construites d'après la Theorie de la Mécanique Céleste; far M. A. Bouvard. 4to pp. 138. Paris, 1821.

I $\mathrm{N}$ the year $1808, \mathrm{M}$. Bouvard, who is well known as an indefa. tigable observer and calculator, constructed tables of Jupiter and Saturn, founded on the system of gravity, and on the several observed oppositions, from 1747 to $1 \mathrm{~S} 04$. Not long after the impression of these tables, M. de Laplace discovered an error in the analytical part of the process used in the construction, which influenced the values of the elliptic elements, and conseguently the tables would not long continue to accord with observation.

Undaunted by this vexatious occurrence, M. Bouvard recommenced his labours, and in the Connaissance des Tems of the year 1816 published corrected elements of Jupiter; in the formation of which were employed all the observed oppositions and quadratures down to 1814. The elements of Saturn, in like manner corrected, appeared in the volume for 1818 ; and those of Uranus were promised.

In the present volume are comprised tables of the three planets constructed according to the decimal division of the circle (as were those of 1808 ); with an introduction detailing the formulia as numerically expounded, and a comparison of the tables witk the places determined by observation.

With regard to the tables of Uranus, two distinct sets of observations were to be regarded; the one comprising those made by accident, while its existence as a planet was unknown; and the other comprehending the observations from 1781 to the present time. Much industry had been employed by Bouvard, as also by Delambre, Burckhardt and others, to detect observations of this planet, as a fixed star, and the number hitherto ascertainert 